\title{
Fatty acids, health lipid indices, and cholesterol content of sheep meat of three breeds from Moroccan pastures
}

\author{
Kamal Belhaj ${ }^{1,2}$, Farid Mansouri ${ }^{1}$, Abdessamad Benmoumen ${ }^{1}$, Marianne Sindic ${ }^{2}$, \\ Marie-Laure Fauconnier ${ }^{3}$, Mohamed Boukharta ${ }^{4}$, C. Hana Serghini ${ }^{1}$, and Ahmed Elamrani ${ }^{1}$ \\ ${ }^{1}$ Laboratory for Improving Agricultural Productions, Biotechnology and Environment (LAPABE), \\ Faculty of Sciences, University Mohammed First, 717, Oujda, 60000, Morocco \\ ${ }^{2}$ Analysis Quality and Risk Unit, Laboratory of Food Quality and Safety (QSPA), \\ Gembloux Agro-Bio Tech, University of Liège, Gembloux, 5030, Belgium \\ ${ }^{3}$ General and Organic Chemistry Unit, Gembloux Agro Bio-Tech, \\ University of Liège, Gembloux, 5030, Belgium \\ ${ }^{4}$ Institute of Agricultural Industries, High School of Charlemagne, Huy, 4500, Belgium \\ Correspondence: Kamal Belhaj (belhaj.kama190@gmail.com)
}

Received: 24 August 2020 - Revised: 20 October 2020 - Accepted: 2 November 2020 - Published: 16 December 2020

\begin{abstract}
The lipid analysis of commercial lamb's meat, from two main Moroccan production areas Middle Atlas and highlands of eastern Morocco, was conducted. This study concerns the lipid quality of sheep meat from Beni Guil (BG) and Timahdite (Ti) as indigenous breeds and that of the Ouled Djellal (ODj) breed of Algerian origin. To study the effect of the geographical area, the meat samples from the Beni Guil breed were taken in the two main locations of this breed: in the region of Ain Beni Mathar (BGA) and that of Tendrara (BGT). The fatty acid profiles of the sheep meats analyzed showed the following: (i) polyunsaturated fatty acid (PUFA) richness was of $12.87 \%$ and $20.59 \%$ respectively for BGA and BGT breeds; (ii) polyunsaturated / saturated fatty acid ratios were ranged between 0.28 to 0.50 respectively for BGA and Ti breed; and (iii) PUFA- $n-3$ content was $1.71 \%$ for ODj breed and $2.13 \%$ for BGA. Thus, the PUFA- $n-6$ / PUFA $n-3$ ratios range between 4.92 and 9.6 for BGA and Ti sheep meat, respectively. The cholesterol content was $0.08 \%$ and $0.12 \%$ of fresh meat respectively for ODj and BGA. Finally, meats of BGA and ODj have similar thrombogenicity (1.23 and 1.27 respectively) and atherogenicity indices ( 0.71 and 0.68 respectively). Statistically, these values were significantly higher than those registered for Ti breed (IT: 1.04 and AI: 0.51). In conclusion, from a nutritional point of view, it can be deduced that these meats have an interesting lipid quality due to their richness in desirable fatty acid $(\mathrm{UFA}+\mathrm{C} 18: 0)$.
\end{abstract}

\section{Introduction}

In human nutrition, red meats often have a bad reputation among dieticians who consider them too rich in fat (Orellana et al., 2009). Cardiovascular diseases (CVDs) and cancer are among the most important causes of human mortality and are strongly related to a diet of cholesterol and saturated fatty acids (Wood et al., 2003). However, the intramuscular fat of meat is a calorically dense macronutrient which plays a key role in human nutrition due to its richness in essential fatty acids (Cabrera and Saadoun, 2014). Several studies showed that red meat from pasture has lower intra- muscular fat and balanced ratios of lipid quality than animals from feedlots (Pordomingo et al., 2012; Saadoun et al., 2013). Indeed, recent studies showed that certain fatty acids (FAs) in these meats can have a very favorable effect on human health, such as rumenic acid (Howes et al., 2015). Human nutritionists, public health institutes, and various authorities are recommending balanced ratios between saturated fatty acids (SFAs) and unsaturated fatty acids (UFAs), especially of polyunsaturated FAs (PUFAs) $n-3$ in favor of $n-6$ FAs (Wood et al., 2004; Simopoulos and Dinicolantonio, 2016). Research around the world is aimed at assess- 
ing the meat quality through the evaluation of the proportions of essential FAs and other human health promoting FA, such as PUFA $n-3$ (Mortimer et al., 2014; Ponnampalam et al., 2014). Furthermore, the ratio of PUFA / SFA, PUFA $n-6$ / PUFA $n-3$ PUFA, hypo/hypercholesterolemic fatty acids, thrombogenicity index, and atherogenic index are important parameters to assess the nutritional quality of meat fat regarding the prevention of CVDs and cancer (Bressan et al., 2011; Troy et al., 2016).

In Morocco, $95 \%$ of the sheep population is composed of local breeds (Beni Guil, Timahdite, Sardi, Boujaâd, and D'man), and its production is mainly based on pastures (Boulanouar and Paquay, 2006; Elbeltagy, 2012). The trend towards the lean meat consumption from pastures places the sheep meats of indigenous breeds in a favorable position compared to those of selected or imported breeds for a better production (breeds that have high productivity). This study concerns the evaluation of lipid quality of sheep meat from Beni Guil (BG) and Timahdite (Ti) as indigenous breeds and that of the Ouled Djellal (ODj) breed of Algerian origin, currently competing with BG in eastern Morocco highlands due to its weight characteristics.

\section{Materials methods}

\subsection{Animal material}

Sheep livestock in Morocco is generally destined for meat production where the majority of the males are intended for the feast of the sacrifice, and about $25 \%$ of female lambs are reserved to replace the elderly ewes. The rest are fattened and intended for slaughter to supply the red meat markets throughout the year. In this study, 48 carcasses of female lambs from three sheep breeds were reared in Moroccan pastures. Two indigenous breeds (Beni Guil $(n=24)$ and Timahdite $(n=12))$ and one non-indigenous breed of Algerian origin called Ouled Djellal $(n=12)$, which cohabits with the Beni Guil sheep in the highlands of eastern Morocco, were used in this research.

Animals were aged between 7 and 8 months, weaned at the age of 3 months, of the $\mathrm{L}$ category according to the regulation of the European Commission no. 823/98. The animals weight at slaughter was between $33-37 \mathrm{~kg}$, with an average-high fattening state, according to the EUROP community scale of grading sheep carcasses (Sagot and Pottier, 2011b) and the conformation ranged between fair $(\mathrm{O})$ to good $(\mathrm{R})$ class according to the EUROP grid (Sagot and Pottier, 2011a).

\subsection{Breeding condition}

The sheep farmers are members of the national association of breed producers (ANOC). They adopt a rhythm of lambing per year. Sampling was done with the assistance of the slaughterhouse veterinarian. Forty-eight longissimus lumborum muscles (LLM) were obtained $24 \mathrm{~h}$ after slaugh- ter. These BG and ODj lambs belong to herds raised in the highlands of eastern Morocco, and the Ti lambs belong to herds raised in the rural commune of El Hajeb (Middle Atlas). The breeds used in this study were reared in the same production and rearing system. The animals in eastern Morocco are reared on natural highlands in an arid to a semiarid environment. The diet of the ewes was composed of natural pastures when available and the same supplementation of 150 to $250 \mathrm{~g}$ per day based on alfalfa hay and barley in drought, hunger season, and in some physiological stages, such as at the time of preparation for breeding (flushing) and for lambing (steaming). The lambing season occurs mainly from September to December. Four weeks before parturition, ewes receive barley supplementation to avoid abortions, as well as to improve milk production and quality after lambing. The lambs are vaccinated $15 \mathrm{~d}$ after lambing for enterotoxemia. In the first two months of age, the lambs stay in the sheepfold during the day, giving them a supplement based on barley and alfalfa hay ad libitum. Then, in the third month of age, the lambs were raised with their mothers until weaning at the age of 3 months and grazed on natural grassland pastures with additional feeding based on barley (100$120 \mathrm{~g} \mathrm{~d}^{-1}$ ) and hay. Before slaughter, the lambs undergo a finishing phase of $45 \mathrm{~d}$ based on barley ( 1 to $1.5 \mathrm{~kg} \mathrm{~d}^{-1}$ ). The lambs have free access to water and mineral supplement in the form of a lick block.

In the pastoral system adopted by breeders of eastern Morocco and the Middle Atlas, the adopted feeding calendar is dominated by grazing that lasts up to $8-12$ months $\mathrm{yr}^{-1}$ depending on climatic conditions (rainfall).

In the eastern region of Morocco, animals move south in winter and north in summer in the same area to graze on the halfah grass (Stipa tenacissima) and wormwood (Artemisia herba-alba) steppes. In July-August, the animals feed on cereal stubbles. The dominant plant species in the steppe and highland pasture of eastern Morocco were wormwood (Artemisia herba-alba), halfah grass (Stipa tenacissima), esparto grass (Lygeum spartum), Atriplex halimus, ray grass (Lolium perenne L.), laser white (Laserpitium latifolium), and sweet broom (Arthrophytum scoparium), with the presence of other species, such as Bromus spp. Eruca vesicaria (roquette), Stipa capensis, and Medicago spp. (Bechchari et al., 2014).

To study the effect of the geographical area, the meat samples from the Beni Guil breed were taken in the two main locations of this breed: in the region of Ain Beni Mathar (BGA) $n=12\left(-2.0247^{\circ}\right.$ longitude, $34.0081^{\circ}$ latitude and $921 \mathrm{~m}$ altitude) and in that of Tendrara (BGT) $n=12$ (longitude: $-2.0^{\circ}$, latitude: $33.04^{\circ}$ and altitude $1442 \mathrm{~m}$ ).

In the Middle Atlas, the pair rangelands-forest is used throughout the year. At an altitude of $1500 \mathrm{~m}$, breeders use stubble and crop residues and co-products from market gardening in summer, fallow in spring, and raw barley in winter. This is the case of the El Hajeb region (longitude $-5.49^{\circ}$, latitude $33.69^{\circ}$, and altitude $773 \mathrm{~m}$ ), where the samples of the 
Timahdite breed were taken. The dominant plant species in this geographical area were Quercus rotundifolia and $Q$. ilex, Stipa tenacissima, Dactylis glomerata, Festuca spp, Cynosurus elegans, Crataegus laciniata, Arrhenatherum elatius, and Juniperus phoenicea, with the presence of other species, such as Avena spp., Papaver spp., Trifolium, Hordeum murinum, and Vicia spp. (Berkat and Tazi, 2004).

\subsection{Preparation of freeze-dried meat}

The samples were frozen, lyophilized, crushed, and stored at $-20{ }^{\circ} \mathrm{C}$ for subsequent analyses.

\subsection{Dry matter and intramuscular fat (IMF) extraction}

Dry matter was calculated using the drying method in a stove at $100 \pm 3{ }^{\circ} \mathrm{C}$ according to the method described by AOAC (1990). IMF was extracted and quantified according to Bligh and Dyer (1959) using a mixture of chloroform / methanol / water mixture $(2 / 1 / 1 ; v / v / v)$.

\subsection{Fatty acid analysis}

The lipid extract was methylated before analysis. The FAs were converted to fatty acid methyl esters (FAMEs) according to the method described by Ben Moumen et al. (2015) using BF3 at $14 \%$ weight in methanol. The separation of the FAMEs was performed on an Agilent gas chromatograph (GC) (HP6890 series, Agilent Technologies, USA) equipped with an Omega wax capillary column $(30 \mathrm{~m} \times 0.25 \mathrm{~mm}$, $0.25 \mathrm{~m}$ film thickness) from Supelco (Bellefonte, PA, USA) and a flame ionization detector (FID). Helium (99.999\%, Air Liquide, Liege, Belgium) was used as the carrier gas, at a flow rate of $1.7 \mathrm{~mL} \mathrm{~min}^{-1}$. The temperatures of the injector and detector were set at 150 and $250{ }^{\circ} \mathrm{C}$, respectively, and the oven temperature was $210^{\circ} \mathrm{C}$. The injection volume was $1 \mu \mathrm{L}$, in split-less mode. A FAME standard, containing 37 components (Supelco, Bellefonte, PA, USA), was used to identify the individual peaks. The average amount of each fatty acid was used to calculate the sum, ratios, and lipid indices of the meat.

\subsection{Cholesterol content}

The cholesterol analysis was carried out according to the method described by Vanderplanck et al. (2011). One gram of fat from each sample is saponified in the presence of $50 \mathrm{~mL}$ of methanolic $\mathrm{KOH}(2 \mathrm{~N})$ at $80^{\circ} \mathrm{C}$ for $1 \mathrm{~h}$ under reflux. After cooling, $1 \mathrm{~mL}$ of betulin solution was added as an internal standard $\left(1 \mathrm{mg} \mathrm{mL}^{-1}\right)$. Then, the solution was diluted with $25 \mathrm{~mL}$ of distilled water. The extraction of the unsaponifiable fraction was carried out three times with $50 \mathrm{~mL}$ diethyl ether. Once the operation is completed, the ethereal extracts containing the unsaponifiable compounds were washed three times with $50 \mathrm{~mL}$ of distilled water and then dried over anhydrous sodium sulfate $\left(\mathrm{NaSO}_{4}\right)$. The diethyl ether was evaporated under reduced pressure at $35^{\circ} \mathrm{C}$ until complete dry. After addition of $1 \mathrm{~mL}$ of chloroform, the fraction was separated by elution with a mixture of chloroform, diethyl ether, and ammonia water $(90: 10: 0.5 ; \mathrm{V} / \mathrm{V})$. The plates were allowed to dry and then were sprayed by 2.7-dichlorofluorescein $0.2 \%$ ethanolic solution, followed by UV examination $(254 \mathrm{~nm})$. The bands corresponding to the sterols were recovered, and the sterols were re-extracted three times with 5,3 , and $3 \mathrm{~mL}$ of chloroform respectively. The obtained extracts were filtered, and the solvent was removed by evaporation with nitrogen. Next, the cholesterol was converted to trimethylsilyl ethers by the addition of $100 \mu \mathrm{L}$ of a $1: 1(\mathrm{~V} / \mathrm{V})$ mixture of anhydrous pyridine and a silylation reagent (trifluoroacetamide and trimethylchlorosilane (BSTFA + TMCS) 99:1 ( $V / V)$ (Supelco, Bellefonte, PA, USA)), and then the mixture was left for $30 \mathrm{~min}$ at $90^{\circ} \mathrm{C}$. The samples were evaporated with nitrogen and then taken up in $1 \mathrm{~mL}$ of hexane. Finally, the mixture was analyzed using gas chromatography (HP 6890 series GC) equipped with a capillary column HP 5 MS (5\%-phenylmethylpolysiloxane, $30 \mathrm{~m} \times 0.25 \mathrm{~mm}, 0.25 \mathrm{~m}$ film thickness) from Supelco (Bellefonte, PA, USA) and a flame ionization detector (FID).

\subsection{Calculations}

Saturated fatty acids (SFAs) were the sum of C14:0, C15:0, C16:0, C17:0, C18:0, C20:0, C22:0, C23:0, and $\mathrm{C} 24: 0$. Monounsaturated fatty acids (MUFAs) were the sum of C14:1, C15:1, C16:1, C17:1, cis/trans-C18:1, $\mathrm{C} 20: 1 n-9$, and $\mathrm{C} 22: 1 n-9$. Polyunsaturated fatty acids (PUFAs) were the sum of $n-3$ (C18:3n3, C20:3n3, $\mathrm{C} 20: 5 n 3$ and $\mathrm{C} 22: 6 n 3), n-6$ (cis/trans-C18:2n6, C18:3n6, $\mathrm{C} 20: 3 n 6$ and $\mathrm{C} 20: 4 n 6)$ fatty acids, C20:2, and C22:2. Unsaturated fatty acids (UFA) were the sum of MUFAs and PUFAs. Desirable fatty acids (DFAs) were C18:0 and UFA. Odd fatty acids (OFAs) were the sum of $\mathrm{C} 15: 0, \mathrm{C} 17: 0, \mathrm{C} 17: 1$, and $\mathrm{C} 23: 0$. Thrombogenic index $(\mathrm{TI})=[\mathrm{C} 14: 0+\mathrm{C} 16: 0+\mathrm{C} 18: 0] /[(0.5 \cdot \mathrm{MUFA})+(0.5$. $n-6)+(3 \cdot n-3)+(n-3 / n-6)]$. Atherogenic index $(\mathrm{AI})=[(4 \cdot 14: 0)+16: 0] /[(\mathrm{AGPI})+(\mathrm{AGMI})] \quad($ Gama et al., 2013). Hypocholesterolemic fatty acids (h) were the sum of C18:1, C18:2n6, C20:4n6, C18:3n3, C20:5n3, C22:5n3, and $\mathrm{C} 22: 6 \omega 3$. Hypercholesteremic fatty acids $(\mathrm{H})$ were the sum of $\mathrm{C} 14: 0$ and $\mathrm{C} 16: 0$. The $\mathrm{h} / \mathrm{H}$ was calculated according to Fernández et al. (2007).

\subsection{Statistical analysis}

Experimental results were expressed as means \pm SD of triplicate determinations. All statistical analyses were conducted using the Statistical Package for the Social Sciences (IBM SPSS 20). The normal distribution was verified according to the Shapiro-Wilk test. One-way ANOVA statistical analysis and Tukey's post hoc test were used for means comparison; 
the difference was considered significant at $p<0.05$. Principal component analysis (PCA) was performed on the chemical data set in order to verify whether it was possible to differentiate the samples according to their meat quality characteristics and to obtain more information on the variables that mainly influence the fatty acid and cholesterol content.

\section{Results and discussion}

\subsection{Fatty acid profile and cholesterol content}

An increasingly important aspect of meat quality is its nutritive value, especially fatty acid composition (Milićević et al., 2014). As a matter of fact, according to recent research, individual or group FAs, namely SFAs, MUFAs, and PUFAs, are present in meat; their ratios and sums are emerging as a key factor in nutrition and health (Vannice and Rasmussen, 2014). Human nutritionists, public health institutes, and various authorities recommend reducing the consumption of SFAs and cholesterol (Yousefi et al., 2012). Red meat lipids are widely criticized for their saturated fatty acid richness (Geay et al., 2002). However, some fatty acids in beef and lamb have health benefits, such as trans vaccenic acid and long-chain PUFA $n-3$ (Howes et al., 2015).

Table 1 does not show a significant difference between the three studied breeds concerning the IMF content (4.6 per $5.73 \%$ ); meanwhile, the cholesterol content is significantly high in the BG breed regardless of its pasture $(0.12 \%-$ $0.11 \%)$ compared to $\mathrm{Ti}(0.1 \%)$ and $\mathrm{ODj}(0.08 \%)$ breeds. The obtained results are in line with the results of several authors (Martínez-Cerezo et al., 2005; Blasco et al., 2019) reporting no variation in intramuscular fat content according to genotype. In accordance with the above results, Vacca et al. (2008) and Sinanoglou et al. (2013) have reported a significant effect of genotype on cholesterol content. However, no effect of breed on the cholesterol content was observed but rather an effect of the diet. Valsta et al. (2005) reported that the cholesterol concentration of meats range between 30 and $120 \mathrm{mg} / 100 \mathrm{~g}$ of meat portion. Our results are lower than those found in the meat of the crossbreed mouflon $\times$ Sarda $(356 \mathrm{mg} / 100 \mathrm{~g}$ of fresh matter); however, they are higher than those reported by Yousefi et al. (2012) for two Iranian breeds $(50.08-53.37 \mathrm{mg}$ per $100 \mathrm{~g}$ of meat) and by Liu et al. (2015) for Oula lamb meat (54.84-60.24 mg per $100 \mathrm{~g}$ of meat). Similar to these findings, Sinanoglou et al. (2013) reported a cholesterol concentration of $90.71 \mathrm{mg} / 100 \mathrm{~g}$ FM in the meat of Karagouniko lamb. According to Kalogeropoulos et al. (2004), the European Olive Oil Medical Information and the World Health Organization have set a maximum daily cholesterol dose of less than $300 \mathrm{mg}$ per day. Thus, the contribution of cholesterol, by consumption of $100 \mathrm{~g}$ of examined sheep meat, represented only $28 \%$ to $39 \%$ of the recommended maximum cholesterol intake.

The gas chromatography analysis of the FA composition allowed the separation and the identification of 26 fatty acids
(Table 2). The main LLM fatty acids of the analyzed meats are, in descending order, oleic acid $(32.06 \%-37.62 \%)$, palmitic acid $(20.72 \%-25.02 \%)$, stearic acid $(12.38 \%-$ $13.78 \%)$, and linoleic acid $(7.37 \%-11.4 \%)$. Saturated fatty acids are often considered undesirable for our health (Wood et al., 2008). However, much research has reported the beneficial effect of the same SFA, such as stearic acid and shortchain FAs (Dietschy, 1998; Bonanome and Grundy, 1988). Stearic acid, in comparison, is assumed to have no effect on blood cholesterol levels and is considered as a good predictor of cover fat firmness of carcasses (Wood et al., 2004). Overall, our results show the prevailing individual saturated FAs were palmitic acid (PA), stearic acid (SA), and myristic acid (MA). The highest values of SFAs were recorded in BGA $(46.53 \%)$ and $\mathrm{ODj}(42.98 \%)$ sheep meat. This difference is mainly related to the proportion of palmitic acid and myristic acid (PA: $25.02 \%, 22.96 \%, 20.72 \%$ and $24.23 \%$; MA: $4.62 \%, 4.34 \%, 2.39 \%$ and $3.53 \%$ respectively for BGA, BGT, Ti, and ODj sheep meat). Ruminant meat is characterized by its high content of SFA due to the ruminal biohydrogenation phenomenon (Ben Abdelmalek et al., 2020). However, several studies showed that it is possible to vary the FA composition by varying the diet and the rearing system (Wood et al., 2003; van Harten et al., 2016; Margetín et al., 2018; Belhaj et al., 2020). The differences in SFA content are more due to the rearing system than the difference in genotype. Indeed, it can be deduced that the meats of BGA and $\mathrm{ODj}$, which were raised in the same rearing system (semiextensive of Ain Beni Mathar) with an important concentrate and halfah-based supplementation, are the richest in SFA. This high content of PA in BG and ODj meats is possibly due to the steppe-pasture diet rich in palmitic acid. In this context, Berrighi et al. (2017) had reported that the chemical composition of the steppe pasture diet contains $24.08 \%$ to $28.48 \%$ of PA. However, our results show no difference between the studied meats in the percentage of stearic acid. The obtained results of SFAs are lower than those reported by Margetín et al. (2018) in the meat of Île-de-France sheep breed and are comparable to those reported by Polidori et al. (2017) in the meat of the Fabrianese breed. The SFAs recorded values in LL muscle of Ti and BGT comparable to those found by Garcia et al. (2008) in the meat of Patagonian lamb.

The MUFA content (Table 3) does not show a significant difference between BGA, Ti, and ODj; on the other hand, a significant lower content was observed for BGT. This difference is notably due to the $\mathrm{C} 18: 1$ content (dominant MUFA), which was considered to be beneficial FAs for decreasing plasma cholesterol and low-density lipoprotein (LDL) (Tejeda et al., 2008; Reddy et al., 2015). Furthermore, our estimates of enzymatic activity of Delta9-desaturase C18 responsible for conversion of $\mathrm{C} 18: 0$ to their cis- 9 monounsaturated, obtained by product-substrate ratios, did not differ significantly among the studied meats (data not shown). Thus, in the case of BGT, it is assumed that the difference in 
Table 1. Moisture, intramuscular fat (IMF), and cholesterol content of Beni Guil (BG), Timahdite (Ti), and Ouled Djellal (ODj) sheep meats from Moroccan pastures.

\begin{tabular}{lrrrrl}
\hline Parameters & \multicolumn{4}{c}{ Breed } & \multirow{2}{*}{ Effect } \\
\cline { 2 - 5 } (\% fresh matter basis) & BGA & BGT & Ti & ODj \\
\hline Moisture & $73.17 \pm 1.34$ & $73.85 \pm 0.94$ & $73.41 \pm 1.27$ & $73.63 \pm 0.76$ & NS \\
IMF & $5.73 \pm 1.31^{\mathrm{b}}$ & $4.80 \pm 1.00^{\mathrm{a}}$ & $5.5 \pm 1.30^{\mathrm{b}}$ & $4.60 \pm 0.88^{\mathrm{a}}$ & NS \\
Cholesterol & $0.12 \pm 0.02^{\mathrm{b}}$ & $0.11 \pm 0.01^{\mathrm{b}}$ & $0.10 \pm 0.01^{\mathrm{a}}, \mathrm{b}$ & $0.08 \pm 0.01^{\mathrm{a}}$ & $* *$ \\
\hline
\end{tabular}

Values in the same row with different superscripts are significantly $(p<0.05)$ different. NS: not significant; ${ }^{*} p<0.05$;

${ }^{* *} p<0.01$; ${ }^{* * *} p<0.001$; BGA: female lambs of Beni Guil breed sampled in the Ain Beni Mathar region; BGT: female lambs of Beni Guil breed sampled in the Tendrera region.

Table 2. Fatty acid profiles of Beni Guil (BG), Timahdite (Ti), and Ouled Djellal (ODj) sheep meats from Moroccan pastures.

\begin{tabular}{|c|c|c|c|c|c|}
\hline \multirow[t]{2}{*}{ Fatty acid (\%) } & \multicolumn{4}{|c|}{ Breed } & \multirow[t]{2}{*}{ Effect } \\
\hline & BGA & BGT & $\mathrm{Ti}$ & ODj & \\
\hline $\mathrm{C} 14: 0$ & $4.62 \pm 1.41^{\mathrm{c}}$ & $4.34 \pm 0.75^{\mathrm{b}, \mathrm{c}}$ & $2.39 \pm 0.69^{\mathrm{a}}$ & $3.53 \pm 0.57^{b}$ & $* * *$ \\
\hline C14: 1 & $0.37 \pm 0.10^{\mathrm{a}}$ & $1.50 \pm 0.19^{\mathrm{c}}$ & $0.32 \pm 0.17^{\mathrm{a}}$ & $1.01 \pm 0.40^{\mathrm{b}}$ & $* * *$ \\
\hline $\mathrm{C} 15: 0$ & $0.58 \pm 0.11$ & $0.58 \pm 0.10$ & $0.51 \pm 0.07$ & $0.53 \pm 0.20$ & NS \\
\hline $\mathrm{C} 15: 1$ & $0.12 \pm 0.05^{\mathrm{a}}$ & $1.27 \pm 0.60^{\mathrm{c}}$ & $0.24 \pm 0.03^{\mathrm{a}}$ & $0.80 \pm 0.13^{\mathrm{b}}$ & $* * *$ \\
\hline $\mathrm{C} 16: 0$ & $25.02 \pm 2^{\mathrm{c}}$ & $22.96 \pm 0.83^{b}$ & $20.72 \pm 1.25^{\mathrm{a}}$ & $24.23 \pm 2.02^{b, c}$ & $* * *$ \\
\hline $\mathrm{C} 16: 1$ & $1.67 \pm 0.29^{\mathrm{c}}$ & $0.90 \pm 0.24^{\mathrm{b}}$ & $1.14 \pm 0.17^{\mathrm{b}}$ & $0.79 \pm 0.29^{\mathrm{a}}$ & $* * *$ \\
\hline $\mathrm{C} 17: 0$ & $1.24 \pm 0.10^{\mathrm{b}}$ & $0.80 \pm 0.13^{\mathrm{a}}$ & $1.74 \pm 0.43^{\mathrm{c}}$ & $1.10 \pm 0.16^{\mathrm{b}}$ & $* * *$ \\
\hline $\mathrm{C} 17: 1$ & $0.9 \pm 0.05^{\mathrm{b}}$ & $0.14 \pm 0.02^{\mathrm{a}}$ & $1.31 \pm 0.28^{\mathrm{c}}$ & $0.15 \pm 0.05^{\mathrm{a}}$ & $* * *$ \\
\hline $\mathrm{C} 18: 0$ & $13.78 \pm 2.32$ & $12.38 \pm 1.28$ & $12.98 \pm 0.77$ & $12.73 \pm 1.89$ & NS \\
\hline Cis/trans-C18: $1 n 9$ & $37.3 \pm 2.78^{b}$ & $32.06 \pm 4.84^{\mathrm{a}}$ & $36.26 \pm 1.77^{b}$ & $37.62 \pm 3.92^{\mathrm{b}}$ & $* * *$ \\
\hline Cis/trans-C18:2n6 & $7.37 \pm 2.11^{\mathrm{a}}$ & $10.68 \pm 1.44^{b}$ & $11.40 \pm 1.56^{\mathrm{c}}$ & $7.90 \pm 1.80^{\mathrm{a}}$ & $* * *$ \\
\hline C18:3n6 (ALA) & $0.83 \pm 0.24^{\mathrm{a}}$ & $1.75 \pm 0.34^{\mathrm{b}}$ & $0.68 \pm 0.30^{\mathrm{a}}$ & $0.78 \pm 0.07^{\mathrm{a}}$ & $* * *$ \\
\hline $\mathrm{C} 18: 3 n 3$ (LA) & $0.90 \pm 0.2^{b}$ & $0.99 \pm 0.30^{\mathrm{b}}$ & $0.49 \pm 0.19^{\mathrm{a}}$ & $0.63 \pm 0.18^{\mathrm{a}}$ & $* * *$ \\
\hline $\mathrm{C} 20: 0$ & $0.23 \pm 0.03^{\mathrm{b}, \mathrm{c}}$ & $0.1 \pm 0.03^{\mathrm{a}}$ & $0.16 \pm 0.05^{\mathrm{a}, \mathrm{b}}$ & $0.29 \pm 0.05^{\mathrm{c}}$ & $* * *$ \\
\hline $\mathrm{C} 20: \ln 9$ & $0.13 \pm 0.03^{\mathrm{a}}$ & $0.4 \pm 0.10^{\mathrm{c}}$ & $0.17 \pm 0.03^{\mathrm{a}}$ & $0.31 \pm 0.07^{b}$ & $* * *$ \\
\hline $\mathrm{C} 20: 2$ & $0.26 \pm 0.10^{\mathrm{a}}$ & $1.47 \pm 0.48^{\mathrm{c}}$ & $0.35 \pm 0.08^{\mathrm{a}}$ & $0.60 \pm 0.20^{\mathrm{b}}$ & $* * *$ \\
\hline $\mathrm{C} 20: 3 n 6$ & $0.19 \pm 0.07^{\mathrm{a}}$ & ND & $0.36 \pm 0.07^{b}$ & ND & $* * *$ \\
\hline $\mathrm{C} 20: 3 n 3$ & $0.08 \pm 0.0 .02^{\mathrm{a}}$ & $0.14 \pm 0.04^{b}$ & $0.09 \pm 0.03^{\mathrm{a}}$ & $0.19 \pm 0.06^{\mathrm{c}}$ & $* * *$ \\
\hline $\mathrm{C} 20: 4 n 6$ (ARA) & $2.09 \pm 0.98^{\mathrm{a}}$ & $4.59 \pm 0.63^{b}$ & $5.52 \pm 1.37^{b}$ & $4.62 \pm 0.63^{b}$ & $* * *$ \\
\hline C20:5n3 (EPA) & $0.39 \pm 0.20^{\mathrm{a}}$ & ND & $0.55 \pm 0.20^{\mathrm{b}}$ & ND & $*$ \\
\hline $\mathrm{C} 22: 0$ & $0.19 \pm 0.04$ & ND & $0.17 \pm 0.03$ & ND & NS \\
\hline $\mathrm{C} 22: \ln 9$ & $0.11 \pm 0.05$ & ND & $0.11 \pm 0.06$ & ND & NS \\
\hline $\mathrm{C} 22: 2$ & ND & $0.25 \pm 0.09$ & ND & $0.36 \pm 0.14$ & NS \\
\hline $\mathrm{C} 23: 0$ & $0.17 \pm 0.06^{\mathrm{a}}$ & $1.67 \pm 0.48^{\mathrm{b}}$ & $0.48 \pm 0.22^{\mathrm{c}}$ & $0.84 \pm 0.17^{\mathrm{d}}$ & NS \\
\hline $\mathrm{C} 24: 0$ & $0.62 \pm 0.29^{b}$ & $0.29 \pm 0.14^{\mathrm{a}}$ & $1.09 \pm 0.30^{\mathrm{c}}$ & $0.16 \pm 0.06^{\mathrm{a}}$ & $* * *$ \\
\hline C22: $6 n 3$ (DHA) & $0.76 \pm 0.13$ & $0.72 \pm 0.16$ & $0.74 \pm 0.26$ & $0.89 \pm 0.22$ & NS \\
\hline
\end{tabular}

Values in the same row with different superscripts are significantly $(p<0.05)$ different. NS: not significant; ND: not detected;

${ }^{*} p<0.05 ;{ }^{* *} p<0.01$; ${ }^{* * *} p<0.001$; BGA: female lambs of Beni Guil breed sampled in the Ain Beni Mathar region; BGT: female lambs of Beni Guil breed sampled in the Tendrera region.

C18: 1 content would not be due to an insufficient synthesis of $\mathrm{C} 18: 1$ from $\mathrm{C} 18: 0$ by desaturation but rather to a less important provision in $\mathrm{C} 18: 0$, to a greater desaturation of $\mathrm{C} 18: 1$ to $\mathrm{C} 18: 2$, or to a more significant bio-hydrogenation of $\mathrm{C} 18: 1$ to $\mathrm{C} 18: 0$. However, the latter hypothesis should also be ruled out since no difference in the $\mathrm{C} 18: 0$ level was observed for the BGT meats compared to the other studied meats. Significant differences $(p<0.05)$ were recorded in the other minor MUFAs such as myristoleic acid (C14:1), 10-pentadecenoic acid (C15:1), palmitoleic acid (C16:1), and 11-eicosenoic acid (C20:1n-9).

Sheep meat is among the sources of essential fatty acids, especially linolenic acid (ALA, $n-3$ ) and long-chain PUFA $n-3$, including eicosapentaenoic acid (EPA, C20:5n3 ) and docosahexaenoic acid (DHA, C22:6 n-3), which have potential benefits concerning heart health (Howes et 
Table 3. Partial sums of fatty acids (g per $100 \mathrm{~g}$ fatty acids), ratios, and indices of Beni Guil (BG), Timahdite (Ti), and Ouled Djellal (ODj) sheep meats from Moroccan pastures.

\begin{tabular}{lrrrrl}
\hline \multirow{2}{*}{ Parameters } & \multicolumn{4}{c}{ Breed } & \multirow{2}{*}{ Effect } \\
\cline { 2 - 5 } & \multicolumn{2}{c}{ BGA } & BGT & Ti & ODj \\
\hline SFA & $46.45 \pm 1.70^{\mathrm{c}}$ & $43.12 \pm 2.15^{\mathrm{b}}$ & $40.24 \pm 1.86^{\mathrm{a}}$ & $43.41 \pm 4.05^{\mathrm{b}}$ & $* * *$ \\
MUFA & $40.6 \pm 5.04^{\mathrm{b}}$ & $36.27 \pm 3.52^{\mathrm{a}}$ & $39.55 \pm 2.86^{\mathrm{b}}$ & $40.68 \pm 3.57^{\mathrm{b}}$ & $* * *$ \\
PUFA & $12.87 \pm 3.61^{\mathrm{a}}$ & $20.59 \pm 3.61^{\mathrm{c}}$ & $20.18 \pm 2.21^{\mathrm{c}}$ & $15.61 \pm 2.71^{\mathrm{b}}$ & $* *$ \\
UFA & $53.47 \pm 1.7^{\mathrm{a}}$ & $56.86 \pm 1.66^{\mathrm{b}}$ & $59.73 \pm 1.68^{\mathrm{c}}$ & $56.29 \pm 4.05^{\mathrm{b}}$ & $* * *$ \\
DFA & $67.25 \pm 3.20^{\mathrm{a}}$ & $69.24 \pm 0.37^{\mathrm{a}}$ & $72.71 \pm 2.5^{\mathrm{b}}$ & $69.02 \pm 2.59^{\mathrm{a}}$ & $* * *$ \\
OFA & $2.99 \pm 0.13^{\mathrm{a}}$ & $4.46 \pm 0.67^{\mathrm{b}}$ & $4.27 \pm 0.76^{\mathrm{b}}$ & $3.42 \pm 0.44^{\mathrm{a}}$ & $* * *$ \\
UFA/SFA & $1.15 \pm 0.07^{\mathrm{a}}$ & $1.32 \pm 0.08^{\mathrm{b}}$ & $1.48 \pm 0.11^{\mathrm{c}}$ & $1.30 \pm 0.19^{\mathrm{b}}$ & $* * *$ \\
PUFA/SFA & $0.28 \pm 0.08^{\mathrm{a}}$ & $0.48 \pm 0.1^{\mathrm{b}}$ & $0.50 \pm 0.15^{\mathrm{c}}$ & $0.36 \pm 0.08^{\mathrm{a}, \mathrm{b}}$ & $* * *$ \\
PUFA $n-6$ & $10.48 \pm 3.31^{\mathrm{a}}$ & $17.02 \pm 1.29^{\mathrm{c}}$ & $17.96 \pm 1.29^{\mathrm{c}}$ & $13.3 \pm 2.89^{\mathrm{b}}$ & $* * *$ \\
PUFA $n-3$ & $2.13 \pm 1.28^{\mathrm{b}}$ & $1.86 \pm 0.46^{\mathrm{a}, \mathrm{b}}$ & $1.87 \pm 0.41^{\mathrm{a}, \mathrm{b}}$ & $1.71 \pm 0.31^{\mathrm{a}}$ & $*$ \\
$n-6 / n-3$ & $4.92 \pm 1.74^{\mathrm{a}}$ & $9.16 \pm 2.7^{\mathrm{b}}$ & $9.60 \pm 3.18^{\mathrm{b}}$ & $7.77 \pm 2.7^{\mathrm{b}}$ & $* * *$ \\
TI & $1.36 \pm 0.10^{\mathrm{c}}$ & $1.23 \pm 0.11^{\mathrm{b}}$ & $1.04 \pm 0.08^{\mathrm{a}}$ & $1.27 \pm 0.17^{\mathrm{b}, \mathrm{c}}$ & $* * *$ \\
AI & $0.83 \pm 0.15^{\mathrm{c}}$ & $0.71 \pm 0.04^{\mathrm{c}, \mathrm{b}}$ & $0.51 \pm 0.08^{\mathrm{a}}$ & $0.68 \pm 0.12^{\mathrm{b}}$ & $* * *$ \\
h/H & $1.73 \pm 0.26^{\mathrm{a}}$ & $1.94 \pm 0.10^{\mathrm{b}}$ & $2.47 \pm 0.25^{\mathrm{c}}$ & $1.96 \pm 0.28^{\mathrm{b}}$ & $* * *$ \\
Nutritive value of fat & $2.05 \pm 0.22^{\mathrm{a}}$ & $1.93 \pm 0.11^{\mathrm{a}}$ & $2.39 \pm 0.21^{\mathrm{b}}$ & $2.09 \pm 0.21^{\mathrm{a}}$ & $* * *$ \\
\hline
\end{tabular}

Values in the same row with different superscripts are significantly $(p<0.05)$ different; BGA: female lambs of Beni Guil breed sampled in the Ain Beni Mathar region; BGT: female lambs of Beni Guil breed sampled in the Tendrera region. SFA: saturated fatty acids; UFA: unsaturated fatty acids; PUFA: polyunsaturated fatty acids; DFA: desirable fatty acids (C18: 0 + UFA); OFA: odd fatty acids; IT: thrombogenic index $=[\mathrm{C} 14: 0+\mathrm{C} 16: 0+\mathrm{C} 18: 0] /\left[(0.5 \cdot \mathrm{MUFA})+\left(0.5 \cdot \sum n-6\right)+\left(3 \cdot \sum n-3\right)+(n-3 / n-6)\right]$. IA: atherogenic index $=[(4 \cdot \mathrm{C} 14: 0)+\mathrm{C} 16: 0] /[$ (PUFA) $+($ MUFA $)]$, calculated as per Ulbrichtet Southgate (1991) without the inclusion of C18: 0, which is considered to be neutral on serum cholesterol; hypocholesterolemic FA (h)/hypercholesterolemic FA $(\mathrm{H})=$ $(18: \ln 9 \mathrm{c}+18: 2 \omega 6+20: 4 \omega 6+18: 3 \omega 3+20: 5 \omega 3+\mathrm{C} 18: 3 \omega 6+\mathrm{C} 20: 3 \omega 6+20: 2+22: 6 \omega 3) /(14: 0+16: 0)$; Nutritive value of fat $=(\mathrm{C} 18: 0+\mathrm{C} 18: 1) / \mathrm{C} 16: 0$.

al., 2015). In this study, the predominant PUFAs in analyzed meats are $\mathrm{C} 18: 2 n-6(7.37 \%-11.40 \%)$ and $\mathrm{C} 20: 4 n 6$ $(2.09 \%-5.52 \%)$. Belhaj et al. (2020) reported similar results for BG sheep meat produced in Ain, Beni Mathar region. The proportion of the PUFAs was significantly higher in the muscle of BGT $(20.2 \%)$ and $\mathrm{Ti}(20.61 \%)$ lambs than in BGA $(12.87 \%)$ and ODj (15.89\%) lambs. Regarding the sums of PUFAs $n-3$, the results show a significant difference between the studied meats, where the higher value was recorded in BGA lambs $(2.13 \%)$ and the lower in ODj lambs $(1.71 \%)$. For BGA and ODj breeds, the obtained results of PUFAs are higher in comparison with those reported by Garcia et al. (2008) for Patagonian (13.85\%) lambs and are lower than those reported by Margetín et al. (2018) for Île-de-France (17.21\%) and by van Harten et al. (2016) for Dorper lambs (16.93\%). Nevertheless, the recorded PUFA values in BGT and Ti lambs are higher than those reported by Margetín et al. (2018) for Île-de-France (16.93\%) lambs and similar to the result obtained by van Harten et al. (2016) for Merino (21.85\%) lambs and by Addis et al. (2013) for Agnello di Sardegna (21.85\%) lambs.

The ratios and indices of FAs classes as affected by breed are presented in Table 3. According to Sinanoglou et al. (2013), these ratios and indices are important keys when assessing the nutritional value of meat fat in regard to the prevention of CVDs and carcinogenicity (Cabrera and Saadoun,
2014). The PUFA / SFA ratios range from 0.28 for BGA breed meat to 0.50 for Ti breed meat. These recorded ratios ( 0.28 vs. 0.36 vs. 0.48 vs. 0.50 for BG, ODj, BGT and Ti respectively) are around the recommended value in human nutrition (0.45) (Wood and Enser, 1997). Thus, the values found in this study were higher than those found by Garcia et al. (2008) for Patagonian lambs (0.35) in Argentina, by Maia et al. (2012) for meat of crossbred lambs (0.2-0.3) in Brazil, by Yousefi et al. (2012) for two Iranian breeds (0.16-0.19), by Liu et al. (2015) for Oula lambs in China, and by Berrighi et al. (2017) for meat reared in highland and steppe in Algeria. Similarly, Faria et al. (2012) reported PUFA / SFA ratios varied between 0.43 and 0.55, and Sinanoglou et al. (2013) reported values between 0.37 and 0.49 , which are lower than those reported for Fabrianese lambs by Polidori et al. (2017). This difference can be attributed to different age at slaughter and to the fact that the studied animals were functional as ruminants, whereas Polidori et al. (2017) used young animals, which are not yet functional as ruminants.

Therefore, Timahdite and BGT meats show the highest PUFA/SFA ratio and are richer in PUFA, which are not only beneficial for health but also for the development of oxidation products during cooking, which will contribute to the great meat flavor. The analysis of the PUFA / SFA ratio results also shows the influence of farming type (way) and feeding on the lipid profile. Thus, the meat of BG breed has 


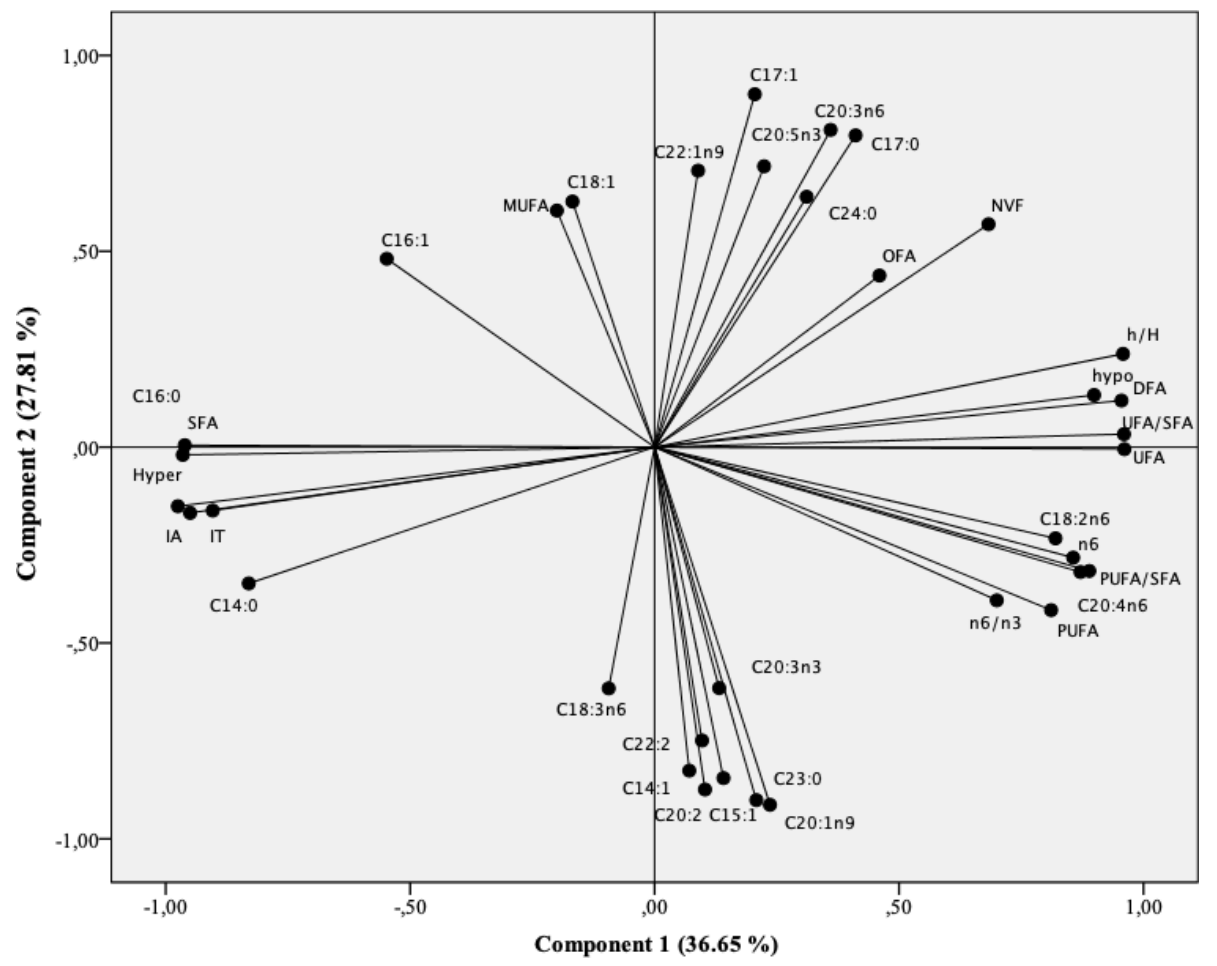

Figure 1. Projection of fatty acids and health lipid indices of intramuscular fat in the plane defined by two principal components.

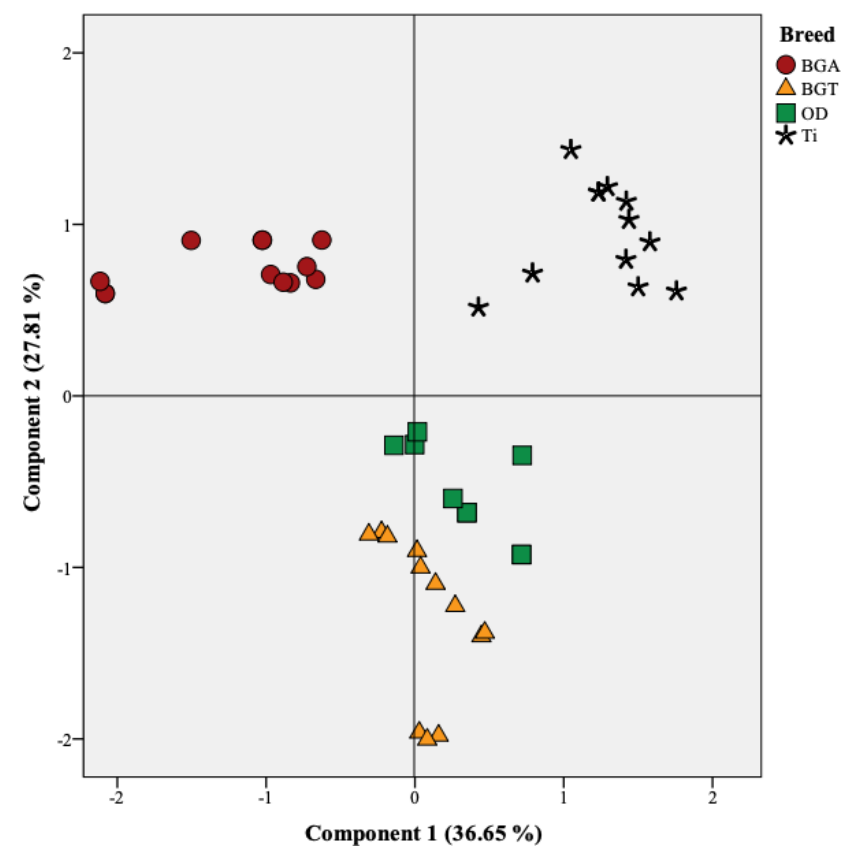

Figure 2. Projection of the variables of the four studied meats in the plane defined by two principal components; BGA: female lambs of Beni Guil sheep breed sampled in the Ain Beni Mathar region; BGT: female lambs of Beni Guil sheep breed sampled in the Tendrera region; ODj: Ouled Djellal sheep breed; Ti: Timahdite sheep breed. a higher PUFA / SFA ratio when the farming method is more extensive in the Tendrera region (BGT; 0.48), where wormwood (Artemisia herba-alba) and halfah (Stipa tenacissima) are not degraded compared to Ain Beni Mathar breeding area (BGA; 0.28), where they are in an advanced degradation state (Bechchari et al., 2014). As a result, breeders in Ain Beni Mathar adopt a semi-extensive rearing method with the use of barley and alfalfa hay supplementation. The richness of the food ration in wormwood (antimicrobial and antioxidant) and halfah, which is rich in unsaturated fatty acids, would be responsible for this difference (Mehdadi et al., 2006; PérezAlvarez and Fernández-López, 2009). Artemisia is rich in active compounds such as antimicrobials that inhibit certain ruminal bacteria, and therefore they would reduce stomach bio-hydrogenation, especially tannins. Thus, they would reduce the oxidative degradation of PUFAs due to the richness of their essential oils in antioxidants (Pérez-Alvarez and Fernández-López, 2009; Vasta et al., 2013; Benouda et al., 2018). The ODj sheep meat has a similar ratio (PUFA / SFA: $0.36)$ to that of the BGA breed, since it was raised practically with the same rearing system: semi-extensive of Ain Beni Mathar region. The meat of Ti breed would have the highest PUFA / SFA and $n-6 / n-3$ ratio, because of the forest-pasture nature, which is characterized by a diet that includes green oak (Quercus Ilex) rich in PUFA. Various studies have already shown the beneficial effect of a diet rich in oak acorns on the meat quality from different domestic animal species (Keddam et al., 2010; Ramdane, 2014; Mekki et 
al., 2019). Indeed, the incorporation of acorns rich in antioxidants especially in tocopherol makes it possible both to improve the PUFA content and to reduce their oxidative degradation, therefore preserving their nutritional quality (Akcan et al., 2017). In addition, this decrease in oxidation would improve the meat color (Jerónimo et al., 2016; Mekki et al., 2019). The presence of tannins in acorns would improve the PUFA / SFA ratio by reducing ruminal bio-hydrogenation. The obtained results correspond to those obtained by several other authors who reported an increase in the PUFA / SFA ratio in free grazing (Wood et al., 2003; Margetín et al., 2018). Thus, the finishing phase of barley-based lambs influences the content of PUFAs. However, the reported results of Sauvant and Bas (2001) and Popova et al. (2015) showed that a concentrated carbohydrate-rich diet would shorten the time food stays in the rumen (congestion time), thereby decreasing their bio-hydrogenation and therefore a reduction in SFA.

The analysis of other calculated lipid indices from the different obtained fatty acids values and which would have a nutritional effect shows significant differences between the four studied meats. From a nutritional point of view, the ratio $n-6 / n-3$ would be among the most important criteria of fat quality. Indeed, according to Simopoulos (2002) this ratio $(n-6 / n-3)$ plays an essential role regarding the risk of atherosclerosis, especially the formation of blood clots leading to a heart attack (Simopoulos, 2002; Howes et al., 2015). The calculation of this ratio shows significant differences between the analyzed meats. Thus, the BGA meat has the lowest ratio (4.92), which is close to the limit values recommended by nutritionists $(<4)$ (Sinanoglou et al., 2013; Howes et al., 2015). The ODj breed meat reared under the same conditions of BGA has a higher ratio of $n-6 / n-3$ (7.77) compared to the nutritional recommendations but lower compared to those obtained for $\mathrm{Ti}$ and BGT meats ( 9.5 and 9.15 respectively). The low value of the $n-6 / n-3$ ratio in ODj and especially BGA meats can be partly explained by the fact that the received food supplement is especially halfah rich in $\mathrm{C} 18: 3 n 3$ fatty acid. Our study carried out in 2016 on the BG breed meat from the Ain Beni Mathar region had already shown the interest of this meat from a nutritional point of view (Belhaj et al., 2018). In fact, the values of the PUFA $n-6$ / PUFA $n-3$ ratio found in the four studied meats were considerably high (ranging from 4.92 in the BGA lambs to 9.6 in the meat of the $\mathrm{Ti}$ breed), considering the fact that the $n-6 / n-3$ ratio intake by humans should not exceed the value of 4 (Simopoulos, 2002; Howes et al., 2015). Similar values have been reported by Berrighi et al. (2017) in Reimbi lamb (crossbreed between BG breed and ODj breed) meats (8.4-12.68) and by Nasri et al. (2011) and Vasta et al. (2013) for meat of Barbarine breed (value around 7). However, the recorded values were lower than those reported by Blasco et al. (2019) for Segureña lambs (15.32-15.47) and were higher than those found by Yousefi et al. (2012) and Margetín et al. (2018) for
Chall and Île-de-France sheep breed. Similar results were reported by Keddam et al. (2010) for $n-6 / n-3$ ratio of ODj breed reared in Algeria (8.97 for ODj with a barely diet and 7.37 for ODj with an oak acorn diet).

According to Sinanoglou et al. (2013), AI and TI should not exceed 1. In this study, the AI-obtained values are below the recommended value and are comparable to those reported by Sinanoglou et al. (2013) for Greek breeds (0.550.73) and by Costa et al. (2018) for lamb meat in Brazil. However, they are lower than those reported by Della Malva et al. (2016) for Altamurana lamb, by Oriani et al. (2005) for Merino (1.35) and by Margetín et al. (2018) for Île-deFrance lambs (0.97). Timahdite meat has the lower AI ratio but the highest $n-6 / n-3$ ratio. This difference can be explained by the fact that AI takes into account both the content of some saturated fatty acids, which would have a harmful effect on human health, and contents of MUFA and PUFA with a beneficial effect in the prevention of vascular accidents. Concerning the TI, the obtained values are higher than the recommended value (1.04-1.36) (Sinanoglou et al., 2013). Palmitic and oleic acids represent the principal total fatty acids; the ratio $(\mathrm{C} 18: 0+\mathrm{C} 18: 1) / \mathrm{C} 16: 0$ is an important criterion to predict the meat lipid quality and is defined as the nutritional value of meat (Maia et al., 2012; Yaranoglu and Ozbeyaz, 2019). In this study, the obtained nutritional values range between 1.93 and 2.39 for BGT and Ti sheep breed respectively. These values are in accordance with those reported by Banskalieva et al. (2000). They reported that, in a normal case, the ratio $(\mathrm{C} 18: 0+\mathrm{C} 18: 1) / \mathrm{C} 16: 0$ found in the literature ranged between 2 and 3 for lamb meat. Thus, our results are comparable to those reported by Liu et al. (2015) and Yaranoglu and Ozbeyaz (2019) for Oula lambs (1.752.46) and for Turkish lambs (2.49-2.67), respectively. Regarding the sums of DFA, the results show a significant difference $(p<0.01)$, with higher values recorded in the meat of Ti lambs $(72.71 \%)$. Our results are similar to those reported by Costa et al. (2018) for lambs in Brazil (72.3\%), to those reported by Yaranoglu and Ozbeyaz (2019) for Turkish lambs (70.64\%-72.10\%), and to the values reported by Banskalieva et al. (2000) for lamb meats (63.97\%-71.81\%). However, they are higher than those reported by Díaz et al. (2003) for Manchega lambs (42.3\%).

\subsection{Principal component analysis}

Principal component analysis (PCA) was conducted to provide an easy visualization of the relationships among fatty acid profile and health lipid indices of the studied meats. This analysis was used to further explore the above results. The results for PCA applied to parameter values are summarized in Figs. 1 and 2. Two principal components were extracted from statistical analysis, which explained $63.17 \%$ of the total variance in the data set. The first and second PCs (PC1 and PC2) accounted for $36.65 \%$ and $27.81 \%$ of the variation, respectively. The PC1 was mainly characterized by hypoc- 
holesterolemic fatty acids, PUFA/SFA ratio, PUFA $n-6$, and C20: $4 n-6$ on the right side, and SFA, AI, TI, and hypercholesterolemic fatty acids on the left side (Fig. 1). The PC2 was defined positively by MUFA especially $n-9$ (C18: $1 n 9$ and $\mathrm{C} 22: \ln 9)$ and by $\mathrm{C} 20: 2, \mathrm{C} 22: 2$ and $\mathrm{C} 23: 0$ in the opposite direction. The individual projections on the factorial map (Fig. 2) show discrimination between the studied meats allows summarizing the interpretations already mentioned above in a very simplified way. In fact, BGA lambs were located on the left side of the Fig. 2 and were clearly differentiated from all lamb breeds. Ti lambs were clearly differentiated from the other lamb types and are located on the right side of the Fig. 22, where PUFA, h/H, PUFA $n-6$, and $\mathrm{P} / \mathrm{S}$ ratios lie. According to the PC2, the effect of geographical area is mainly manifested. In fact, the BGA was opposed to BGT on the second PC. The animals sampled in Ain Beni Mathar region are characterized by MUFA richness compared to those sampled in the Tendrera region.

PCA analysis exposed clearly the breed and geographical area effects on the fatty acid composition and intramuscular fat quality of the studied meats. Therefore, the breed and geographical area impact leads to significant differences in lipid quality $(p<0.05)$, which most probably results from the feeding effect and genetic differences, as already mentioned by relevant studies in sheep and cattle (Zhang et al., 2008; Matsuhashi et al., 2011).

\section{Conclusions}

All obtained results clearly show that significant differences are noted on the lipid composition of the longissimus lumborum muscle of the studied breed in Moroccan livestock. The intramuscular fat content does not seem to be affected in this study either by race or by the farming method. Analysis of the fatty acid composition and lipid indices shows that meat of Ti breed has the best lipid profile with its richness in PUFA, its low value of AI, and its high DFA content. The richness in PUFA can be explained by its agrosilvopastoral rearing mode or/and by the pasture quality, rather than a difference in racial origin. Among the four studied breeds, the Ti breed is the only one whose diet is rich in oak acorns. Nevertheless, further studies are needed to confirm these results and to ascertain the mechanisms of action of Moroccan medicinal plants such as wormwood and halfah in eastern Morocco and acorn oak in the Middle Atlas on lipid metabolism in ruminants to determine the origin of this richness in PUFA.

Data availability. The original data of the paper are available upon request to the corresponding author.

Author contributions. KB was responsible for designing the research methodology, carried out all experimental tasks, and wrote the first draft of manuscript; MF for statistical analysis and data interpretation; $\mathrm{AB}$ for data collection and literature review; MS and MB for data analysis and interpretation; MLF for designing the research methodology, data analysis, CHS and AE conceived of the study, its design and coordination, supervising all analyses, and finishing the final version of the manuscript.

Competing interests. The authors declare that they have no conflict of interest.

Acknowledgements. We are grateful to the Moroccan-Belgian bilateral cooperation program for the financial support of this research through "WBI-Project 1-6" 2015-2017. Our thanks are also due to the ANOC "Association Nationale Ovine et Caprine" for its collaboration, particularly to Abdellah Kacem, Belhaj Belhaj, and Abderahman Elmejdoubi.

Financial support. This research has been supported by Wallonie-Bruxelles International (grant no. Project 1-6).

Review statement. This paper was edited by Steffen Maak and reviewed by Ikhlass El Berbri and one anonymous referee.

\section{References}

Addis, M., Fiori, M., Manca, C., Riu, G., and Scintu, M. F.: Muscle colour and chemical and fatty acid composition of "Agnello di Sardegna” PGI suckling lamb, Small Ruminant Res., 115, 5155, 2013.

AOAC: Official Methods of Analysis of the Association of Official Analytical Chemists, 15th edn., Association of Official Analytical Chemists, Washington, p. 1228, 1990.

Akcan, T., Gökçe, R., Asensio, M., Estévez, M., and Morcuende, D.: Acorn (Quercus spp.) as a novel source of oleic acid and tocopherols for livestock and humans: discrimination of selected species from Mediterranean forest, Food Sci. Biotechnol., 54, 3050-3057, 2017.

Banskalieva, V., Sahlu, T. A., and Goetsch, A.: Fatty acid composition of goat muscles and fat depots: a review, Small Ruminant Res., 37, 255-268, 2000.

Bechchari, A., El Aich, A., Mahyou, H., Baghdad, B., and Bendaou, M.: Study of the degradation of steppic rangelands in Béni Mathar and Maâtarka communes (Northeastern of Morocco), J. Mater. Environ. Sci., 5, 2572-2583, 2014.

Belhaj, K., Mansouri, F., Fauconnier, M.-L., Boukharta, M., Caid, H. S., Sindic, M., and Elamrani, A.: Physicochemical and nutritional characteristics of Béni Guil lamb meat raised in eastern Morocco, Med. J. Nutr. Metab., 11, 175-185, 2018.

Belhaj, K., Mansouri, F., Sindic, M., Taaifi, Y., Boukharta, M., Serghini-Caid, H., and Elamrani, A.: Effect of the concentratebased finishing on the proximate composition, organoleptic quality and fatty acids profile of the Beni-Guil sheep meat, E3S Web Conf., 04001, 2020. 
Ben Abdelmalek, Y., Smeti, S., Essid, I., Yagoubi, Y., Tibaoui, S., and Atti, N.: The effect of Rosemary (Rosmarinus officinalis L.) distillation residues and linseed supply on fatty acid profile, meat colour, lipid oxidation and sensorial and hygienic quality of cull Barbarine ewes' meat, J. Anim. Physiol. Anim. Nutr., 00, 1-11, 2020.

Ben Moumen, A., Mansouri, F., Richard, G., Abid, M., Fauconnier, M. L., Sindic, M., El Amrani, A., and Serghini Caid, H.: Biochemical characterisation of the seed oils of four safflower (Carthamus tinctorius) varieties grown in north-eastern of Morocco, Int. J. Food Sci. Technol., 50, 804-810, 2015.

Benouda, H., Bouammali, B., Challioui, A., Oulmidi, A., and Dardouri, N.: Essential oil variation in wild-growing populations of Artemisia herba-alba Asso collected from Morocco: Chemical composition and multivariate analysis, J. Mater. Environ. Sci., 9, 1741-1749, 2018.

Berkat, O. and Tazi, M.: Profil fourrager, Lait (millions de litres), 780, 625, 2004.

Berrighi, N., Belkacemi, L., Bouderoua, K., Santaella, M., Ros, G., and Nieto, G.: Fatty Acids Composition and Sensory Properties of Lamb Meat Fed on Steppe and Highland Pastures, Asian J. Anim. Sci., 11, 88-95, 2017.

Blasco, M., Campo, M. M., Balado, J., and Sañudo, C.: Effect of Texel crossbreeding on productive traits, carcass and meat quality of Segureña lambs, J. Sci. Food Agric., 99, 3335-3342, 2019.

Bligh, E. G. and Dyer, W. J.: A rapid method of total lipid extraction and purification, Can. J. Biochem. Physiol. Links., 37, 911-917, 1959.

Bonanome, A. and Grundy, S. M.: Effect of dietary stearic acid on plasma cholesterol and lipoprotein levels, New N. Engl. J. Med., 318, 1244-1248, 1988.

Boulanouar, B. and Paquay, R.: L'élevage du mouton et ses systèmes de production au Maroc, Institut National de la Recherche Agronomique, Rabat, 2006.

Bressan, M., Rossato, L., Rodrigues, E., Alves, S., Bessa, R., Ramos, E., and Gama, L.: Genotype $\times$ environment interactions for fatty acid profiles in Bos indicus and Bos taurus finished on pasture or grain, J. Anim. Sci., 89, 221-232, 2011.

Cabrera, M. and Saadoun, A.: An overview of the nutritional value of beef and lamb meat from South America, Meat Sci., 98, 435444, 2014.

Costa, J. B., Oliveira, R. L., Silva, T. M., Barbosa, A. M., Borja, M. S., de Pellegrini, C. B., da Silva Oliveira, V., Ribeiro, R. D. X., and Bezerra, L. R.: Fatty acid, physicochemical composition and sensory attributes of meat from lambs fed diets containing licuri cake, PloS one, 13, e0206863, https://doi.org/10.1371/journal.pone.0206863, 2018.

Díaz, M., Velasco, S., Pérez, C., Lauzurica, S., Huidobro, F., and Cañeque, V.: Physico-chemical characteristics of carcass and meat Manchego-breed suckling lambs slaughtered at different weights, Meat Sci., 65, 1247-1255, 2003.

Della Malva, A., Albenzio, M., Annicchiarico, G., Caroprese, M., Muscio, A., Santillo, A., and Marino, R.: Relationship between slaughtering age, nutritional and organoleptic properties of Altamurana lamb meat, Small Ruminant Res., 135, 39-45, 2016.

Dietschy, J. M.: Dietary fatty acids and the regulation of plasma low density lipoprotein cholesterol concentrations, Nutr. J., 128, 444-448, 1998.
Elbeltagy, A.: Characterization and value addition to local breeds and their products in the Near East and North Africa, in: Regional Workshop Rabat, Morocco, FAO, Rabat, Morocco, 19-21, 2012.

Faria, P., Bressan, M., Vieira, J., Vicente-Neto, J., Ferrão, S., Rosa, F., Monteiro, M., Cardoso, M., and Gama, L.: Meat quality and lipid profiles in crossbred lambs finished on clover-rich pastures, Meat Sci., 90, 733-738, 2012.

Fernández, M., Ordóñez, J. A., Cambero, I., Santos, C., Pin, C., and de la Hoz, L.: Fatty acid compositions of selected varieties of Spanish dry ham related to their nutritional implications, Food Chem., 101, 107-112, 2007.

Gama, L., Bressan, M., Rodrigues, E., Rossato, L., Moreira, O., Alves, S., and Bessa, R.: Heterosis for meat quality and fatty acid profiles in crosses among Bos indicus and Bos taurus finished on pasture or grain, Meat Sci., 93, 98-104, 2013.

Garcia, P., Casal, J., Fianuchi, S., Magaldi, J., Rodríguez, F., and Nancucheo, J.: Conjugated linoleic acid (CLA) and polyunsaturated fatty acids in muscle lipids of lambs from the Patagonian area of Argentina, Meat Sci., 79, 541-548, 2008.

Geay, Y., Bauchart, D., Hocquette, J.-F., and Culioli, J.: Valeur diététique et qualités sensorielles des viandes de ruminants. Incidence de l'alimentation des animaux, Prod. Anim., 1, 37-52, 2002.

Howes, N. L., Bekhit, A. E. D. A., Burritt, D. J., and Campbell, A. W.: Opportunities and implications of pasture-based lamb fattening to enhance the long-chain fatty acid composition in meat, Compr. Rev. Food Sci. Food Saf., 14, 22-36, 2015.

Jerónimo, E., Pinheiro, C., Lamy, E., Dentinho, M. T., SalesBaptista, E., Lopes, O., and Silva, F.: Tannins in ruminant nutrition: Impact on animal performance and quality of edible products, in: In Tannins: biochemistry, food sources and nutritional properties, Nova Science Publishers, NY, USA, 121-168, 2016.

Kalogeropoulos, N., Andrikopoulos, N. K., and Hassapidou, M.: Dietary evaluation of Mediterranean fish and molluscs pan-fried in virgin olive oil, J. Sci. Food Agric., 84, 1750-1758, 2004.

Keddam, R., Bouderoua, K., El-Affifi, M., and Selselet-Attou, G.: Growth performances, carcasses parameters and meat fatty acid composition of lamb fed green oak acorns (Quercus ilex) based diet, Afr. J. Biotechnol., 9, 4631-4637, 2010.

Liu, J.-B., Guo, J., Wang, F., Yue, Y.-J., Zhang, W.-L., Feng, R.L., Guo, T.-T., Yang, B.-H., and Sun, X.-P.: Carcass and meat quality characteristics of Oula lambs in China, Small Ruminant Res., 123, 251-259, 2015.

Maia, M. d. O., Costa, F. d. S., Susin, I., Rodrigues, G. H., Ferreira, E. M., Pires, A. V., Gentil, R. S., and Mendes, C. Q.: Efeito do genótipo sobre a composição química e o perfil de ácidos graxos da carne de borregas, R. Bras. Zootec., 41, 986-992, 2012.

Margetín, M., Oravcová, M., Margetínová, J., and Kubinec, R.: Fatty acids in intramuscular fat of Ile de France lambs in two different production systems, Arch. Anim. Breed., 61, 395-403, 2018.

Martìnez-Cerezo, S., Sañudo, C., Panea, B., Medel, I., Delfa, R., Sierra, I., Beltrán, J., Cepero, R., and Olleta, J.: Breed, slaughter weight and ageing time effects on physico-chemical characteristics of lamb meat, Meat Sci., 69, 325-333, 2005.

Matsuhashi, T., Maruyama, S., Uemoto, Y., Kobayashi, N., Mannen, H., Abe, T., Sakaguchi, S., and Kobayashi, E.: Effects of bovine fatty acid synthase, stearoyl-coenzyme A desaturase, sterol regulatory element-binding protein 1 , and growth hormone gene 
polymorphisms on fatty acid composition and carcass traits in Japanese Black cattle, J. Anim. Sci., 89, 12-22, 2011.

Mehdadi, Z., Benaouda, Z., Belbraouet, S., Benhassaini, H., Hamel, L., and Benali, M.: Évolution saisonnière de la composition foliaire de Stipa tenacissima L. en lipides totaux et en acides gras, Sci. Change. Planét./Sécheresse, 17, 493-498, 2006.

Mekki, I., Smeti, S., Hajji, H., Yagoubi, Y., Mahouachi, M., and Atti, N.: Effect of oak acorn (Quercus ilex) intake during suckling and fattening of Barbarine lambs on growth, meat quality and fatty acid profile, J. Anim. Feed Sci., 28, 22-30, 2019.

Milićević, D., Vranić, D., Mašić, Z., Parunović, N., Trbović, D., Nedeljković-Trailović, J., and Petrović, Z.: The role of total fats, saturated/unsaturated fatty acids and cholesterol content in chicken meat as cardiovascular risk factors, Lipids Health Dis., $13,1-12,2014$

Mortimer, S., Van der Werf, J., Jacob, R. H., Hopkins, D., Pannier, L., Pearce, K., Gardner, G., Warner, R. D., Geesink, G., and Edwards, J. H.: Genetic parameters for meat quality traits of Australian lamb meat, Meat Sci., 96, 1016-1024, 2014.

Nasri, S., Salem, H. B., Vasta, V., Abidi, S., Makkar, H., and Priolo, A.: Effect of increasing levels of Quillaja saponaria on digestion, growth and meat quality of Barbarine lamb, Anim. Feed Sci. Technol., 164, 71-78, 2011.

Orellana, C., Peña, F., García, A., Perea, J., Martos, J., Domenech, V., and Acero, R.: Carcass characteristics, fatty acid composition, and meat quality of Criollo Argentino and Braford steers raised on forage in a semi-tropical region of Argentina, Meat Sci., 81, 57-64, 2009.

Oriani, G., Maiorano, G., Filetti, F., Di Cesare, C., Manchisi, A., and Salvatori, G.: Effect of age on fatty acid composition of Italian Merino suckling lambs, Meat Sci., 71, 557-562, 2005.

Pérez-Alvarez, J. A. and Fernández-López, J.: Color measurements on muscle-based foods, in: Handbook of food and muscle analysis, edited by: Nollet, L. M. L. and Toldra, F., Taylor \& Francis Group, New York, 467-478, 2009.

Polidori, P., Pucciarelli, S., Cammertoni, N., Polzonetti, V., and Vincenzetti, S.: The effects of slaughter age on carcass and meat quality of Fabrianese lambs, Small Ruminant Res., 155, 12-15, 2017.

Ponnampalam, E. N., Butler, K. L., Pearce, K. M., Mortimer, S. I., Pethick, D. W., Ball, A. J., and Hopkins, D. L.: Sources of variation of health claimable long chain omega-3 fatty acids in meat from Australian lamb slaughtered at similar weights, Meat Sci., 96, 1095-1103, 2014.

Popova, T., Gonzales-Barron, U., and Cadavez, V.: Meta-análisis del efecto del pastoreo versus la crianza intensiva en los ácidos grasos saturados en la carne de cordeiro, XVI Jornadas sobre Producción Animal, 2, 606-608, 2015.

Pordomingo, A. J., García, T., and Lagreca, G. V.: Effect of feeding treatment during the backgrounding phase of beef production from pasture on: II. Longissimus muscle proximate composition, cholesterol and fatty acids, Meat Sci., 90, 947-955, 2012.

Ramdane, K.: Composition biochimique et propriétés organoleptiques de la viande d'agneaux nourris aux glands de chêne vert (Quercus ilex), Afr. J. Biotechnol., 9, 4631-4637, 2014.

Reddy, K. J., Jayathilakan, K., and Pandey, M.: Olive oil as functional component in meat and meat products: a review, J. Food Sci. Technol., 52, 6870-6878, 2015.
Saadoun, A., Terevinto, A., and Cabrera, M.: Fatty acid composition of meat from Hereford and Braford breed produced on pasture in Uruguay, Ann. Nutr. Metab., 63 (Suppl. 1), 1529, 2013.

Sagot, L. and Pottier, E.: La grille de classement pour la conformation, available at: http://idele.fr/ filieres/bovin-lait/publication/idelesolr/recommends/

la-grille-europ-de-classement-pour-la-conformation.html (last access: 17 March 2020), 2011 a.

Sagot, L. and Pottier, E.: La grille EUROP de classement pour l'état d'engraissement, available at: http: //idele.fr/filieres/bovin-lait/publication/idelesolr/recommends/ la-grille-europ-de-classement-pour-letat-dengraissement.html (last access: 17 March 2020), 2011 b.

Sauvant, D. and Bas, P.: La digestion des lipides chez le ruminant, Prod. Anim., 5, 303-310, 2001.

Simopoulos, A. P.: The importance of the ratio of omega-6/omega-3 essential fatty acids, Biomed. Pharmacother., 56, 365-379, 2002.

Simopoulos, A. P. and Dinicolantonio, J. J.: The importance of a balanced $\omega-6$ to $\omega-3$ ratio in the prevention and management of obesity, Arch. Dis. Child., 3, 1-6, 2016.

Sinanoglou, V. J., Batrinou, A., Mantis, F., Bizelis, I., and MiniadisMeimaroglou, S.: Lipid quality indices: Differentiation of suckling lamb and kid breeds reared by traditional sheep farming, Small Ruminant Res., 113, 1-10, 2013.

Tejeda, J. F., Peña, R. E., and Andrés, A. I.: Effect of live weight and sex on physico-chemical and sensorial characteristics of Merino lamb meat, Meat Sci., 80, 1061-1067, 2008.

Troy, D. J., Tiwari, B. K., and Joo, S.-T.: Health implications of beef intramuscular fat consumption, Korean J. Food Sci. An. Resour., 36, 577-582, 2016.

Ulbricht, T. and Southgate, D.: Coronary heart disease: seven dietary factors, The Lancet, 338, 985-992, 1991.

Vacca, G. M., Carcangiu, V., Dettori, M. L., Pazzola, M., Mura, M. C., Luridiana, S., and Tilloca, G.: Productive performance and meat quality of Mouflon $\times$ Sarda and Sarda $\times$ Sarda suckling lambs, Meat Sci., 80, 326-334, 2008.

Valsta, L., Tapanainen, H., and Männistö, S.: Meat fats in nutrition, Meat Sci., 70, 525-530, 2005.

Vanderplanck, M., Michez, D., Vancraenenbroeck, S., and Lognay, G.: Micro-quantitative method for analysis of sterol levels in honeybees and their pollen loads, Anal. Lett., 44, 1807-1820, 2011.

van Harten, S., Kilminster, T., Scanlon, T., Milton, J., Oldham, C., Greeff, J., and Almeida, A. M.: Fatty acid composition of the ovine longissimus dorsi muscle: effect of feed restriction in three breeds of different origin, J. Sci. Food Agric., 96, 1777-1782, 2016.

Vannice, G. and Rasmussen, H.: Position of the academy of nutrition and dietetics: dietary fatty acids for healthy adults, J. Acad. Nutr. Diet., 114, 136-153, 2014.

Vasta, V., Aouadi, D., Brogna, D. M., Scerra, M., Luciano, G., Priolo, A., and Salem, H. B.: Effect of the dietary supplementation of essential oils from rosemary and artemisia on muscle fatty acids and volatile compound profiles in Barbarine lambs, Meat Sci., 95, 235-241, 2013.

Wood, J. and Enser, M.: Factors influencing fatty acids in meat and the role of antioxidants in improving meat quality, Br. J. Nutr., 78, S49-S60, 1997. 
Wood, J., Enser, M., Fisher, A., Nute, G., Whittington, F., and Richardson, R.: Effects of diets on fatty acids and meat quality, Cah. Options Mediterr. Ser. A, 67, 133-141, 2003.

Wood, J., Richardson, R., Nute, G., Fisher, A., Campo, M., Kasapidou, E., Sheard, P., and Enser, M.: Effects of fatty acids on meat quality: a review, Meat Sci., 66, 21-32, 2004.

Wood, J., Enser, M., Fisher, A., Nute, G., Sheard, P., Richardson, R., Hughes, S., and Whittington, F.: Fat deposition, fatty acid composition and meat quality: A review, Meat Sci., 78, 343-358, 2008.
Yaranoglu, B. and Ozbeyaz, C.: Quality characteristics and fatty acid profiles of Bafra, Akkaraman, and Bafra $\times$ Akkaraman F1 lamb meat, Turk. J. Vet. Anim. Sci., 43, 380-390, 2019.

Yousefi, A. R., Kohram, H., Shahneh, A. Z., Nik-Khah, A., and Campbell, A. W.: Comparison of the meat quality and fatty acid composition of traditional fat-tailed (Chall) and tailed (Zel) Iranian sheep breeds, Meat Sci., 92, 417-422, 2012.

Zhang, S., Knight, T. J., Reecy, J. M., and Beitz, D. C.: DNA polymorphisms in bovine fatty acid synthase are associated with beef fatty acid composition 1, Anim. Genet., 39, 62-70, 2008. 